\title{
Amelioration of Soil: Based on Mineral (Zeolite) Source: A Review
}

\author{
Pawan Kumar Pant ${ }^{1 *}$, Aakash Mishra ${ }^{2}$ and Pallavi Bhatt ${ }^{3}$ \\ ${ }^{1}$ Soil and Land Use Survey of India, Department of Agriculture, Cooperation \& Farmers Welfare, India \\ ${ }^{2}$ Department of Soil Science and Agriculture Chemistry, Anand Agriculture University, India \\ ${ }^{3}$ Department of Soil Science, Govind Ballabh Pant University of Agriculture and Technology, Pantnagar, Uttarakhand, India
}

Submission: December 17, 2019; Published: February 24, 2020

*Corresponding author: Pawan Kumar Pant, Soil and Land Use Survey of India, Department of Agriculture Cooperation \& Farmers Welfare, New Delhi, India

\begin{abstract}
Mineral based amelioration has been used for decades but Indian agriculture is seeking new alternative potentialized source for soil amendment to feed the soil without jeopardizing the sustainability and fertility of soil. A variety of mineral types are commonly used to amend contaminated soils, with different modes of molecular-scale sequestration. Natural zeolite with this prospective exhibited a much higher capacity to ameliorate ill soils through adsorption, cation exchange capacity catalysis and dehydration capacities than either sawdust or other cleaning sources. Zeolites are, therefore, used as a promoter for better crop production and improving soil health by enhancing the value of fertilizers, retaining valuable nutrients as well as improving the quality of resulting manures.
\end{abstract}

Keywords: Zeolite; Amelioration; Soil

\section{Introduction}

Soil amelioration describes any substances added to the soil to improve or modify its qualities and the conditions including physical, chemical, and biological conditions. Such an amended soil is a conditioned and a fertilized one. However, the selection of amendment may depend upon the degree of soil degradation, its composition and the climate etc. A suitable amendment to a situation may not be useful in other conditions [1]. In amelioration techniques of soil, various amendments particularly the inorganic amendments such as gypsum, lime, zeolites, altered rocks, ceramic, perlite, ash, slag, zeolite, pyrites, dolomite, calcined clay, etc. are used. Amongst, zeolitic represents a special niche in this category. There are about 40 identified natural zeolites [2] and more than 150 zeolites have been synthesized. The aim of any in-situ amendment technologies is to sequester and stabilize contaminants in soils or sediments in order to reduce their ability to partition to water or biota, and bring the physicochemical environment of soil in order to provide most supportive conditions for plant growth and microbial actions. Zeolites are hydrated aluminosilicate minerals made from interlinked tetrahedra of alumina $\left(\mathrm{AlO}_{4}\right)$ and silica $\left(\mathrm{SiO}_{4}\right)$. They are solid with a relatively open, three-dimensional crystal structure built from the element's aluminum, oxygen, and silicon, with alkali or alkalineEarth metals (such as sodium, potassium, and magnesium) plus water molecules trapped in the gaps between them. Zeolites are crystalline, microporous aluminosilicates with relatively high cation exchange capacities (CECs), typically on the order of 250 cmolc=kg (Dyer 1988; Evans et al. 1990) and can retain water and negative charge capably to change heavy metals [3]. As a result, zeolites commonly are used commercially as adsorbents for removal of cations from wastewater (Jacobs and Forstner 1999; Yuan et al. 1999; Erdem et al. 2004; Inglezakis 2005). However, zeolites are used for various applications in industry, agriculture and environmental protection. Unlike other soil amendments (e.g. lime) zeolite does not break down over time but remains in the soil to improve nutrient retention. Therefore, its addition to soil will significantly reduce water and fertilizer costs by retaining beneficial nutrients in the root zone. The porous structure of natural zeolite helps to keep the soil aerated and moist as well as active for a long time. The most common zeolites in sedimentary deposits are analclime, chabazite, clinoptilolite, erionite, heulandite, laumontite, mordenite, phillipsite, and wairakite, with clinoptilolite ranking first in abundance.

\section{Occurrence of Zeolites Mineral in India}

The use of natural zeolites has been continuously increasing over past years. The countries like Cuba, USA., Russia, Japan, Italy, South Africa, Hungary and Bulgaria have important resources of these minerals and production potentials [4]. In India zeolites in rocks were reported and mapped in the western part of 
Maharashtra. Sukheswala et al. [5] established that zeolites are distributed in India under three different vertical zones viz., the uppermost Heulandite zone, the middle Scolecite zone and the lower Laumontite zone. In the Deccan Traps of Western India zeolite zoning was first suggested by Walker [6] and confirmed the presence of three zones, laumontite, scolecite, and heulandite, in ascending order. They are distributed based on their frequency of occurrence and the nomenclature of the zone thereby, to identify the highest frequency zone of occurrence of the mineral [7]. Mostly, this mineral is occupied particularly in the pockets of Bombay, Vadodara, Poona and Nasik region within Western Deccan Traps [5]. The areas where rock systems contain zeolites are predominantly occupied by black soils which are spatially associated with red soils. All these soils are endowed with Ca-rich zeolites in sand, silt and clay fractions $[8,9]$.

\section{Distribution of Zeolitic Soils in India}

Zeolitic soils have been estimated to occupy 2.8mha, which constitutes nearly $1 \%$ of the total geographical area of the country. The arid and semi-arid climate constitutes $86 \%$ area of zeolitic soils in India. More than $60 \%$ area of zeolitic soils is found in Maharashtra, Madhya Pradesh and Andhra Pradesh (Table 1). The black cotton soil region occupies around $92 \%$ area representing 21 AERs and 24 bioclimatic systems [10].

Table 1: Chemical Composition of Indian Natural Zeolite [30].

\begin{tabular}{|c|c|c|c|c|c|c|c|c|c|c|c|}
\hline \multirow{3}{*}{$\begin{array}{l}\text { Indian } \\
\text { Zeolite }\end{array}$} & \multicolumn{11}{|c|}{ Weight (\%) } \\
\hline & $\mathrm{SiO}_{2}$ & $\mathrm{TiO}_{2}$ & MnO & $\mathrm{CaO}$ & $\mathrm{K}_{2} \mathrm{O}$ & $\mathrm{Al}_{2} \mathrm{O}_{3}$ & $\mathrm{Na}_{2} \mathrm{O}$ & $\mathbf{F e}_{2} \mathbf{O}_{3}$ & MgO & $\mathbf{P}_{2} \mathbf{O}_{5}$ & $\mathrm{H}_{2} \mathrm{O}$ \\
\hline & 68.03 & 0.21 & 0.01 & 2.65 & 2.26 & 11.92 & 1.96 & 1.77 & 0.83 & 0.06 & 10.25 \\
\hline
\end{tabular}

\section{Functioning of Zeolites in Soil}

Zeolite acts as molecular sieves because of their specific threedimensional structure [11]. Zeolites have a high porosity. Their sieving behavior in soil allows the selective penetration of particles of a certain size, dehydration and hydration of the crystals, the exchange of water to other molecules and the exchange of ions to different ones. In contrast to other known absorbents such as activated carbon or activated alumina, zeolites have a regular, replicable structure of internal pores and channels from 0.3 to $0.15 \mathrm{~nm}[12]$.

\section{Impact of amendment material (zeolite) on soil properties}

The main objective of the amendments is to improve the use of the soil for agricultural purposes. The amendments may be natural or synthetic and by their origin organic or inorganic. Among amendments the inorganic ones are recommended, such as gypsum, lime, zeolites, altered rocks, ceramic, perlite, ash, slag, zeolite, pyrites, dolomite, calcined clay, etc. They contain a variable amount of nutrients, which can affect the $\mathrm{pH}$.

\section{Reducing soil bulk density and improving water retention capacity of soil}

Bulk density of zeolite minerals can be as low as $0.8 \mathrm{Mg} \mathrm{m}^{-3}$ due to the porous nature [13]. Githinji et al. [14] reported application of zeolite $(0.55-0.6 \mathrm{~mm})$ at a $15 \%\left(\mathrm{v} \mathrm{v}^{-1}\right)$ rate to sand $(0.31 \mathrm{~mm})$ media decreased the bulk density from 1.67 to $1.56 \mathrm{Mg} \mathrm{m}^{-3}$ and increased the available water content by 2 times. Zeolite may hold water more than half of their weight due to high porosity of the crystalline structure. Amendment of sand with zeolite increases available water to the plants by 50\% [15]. Zeolite works as a longlasting water reservoir. Water withholds in small capillary for longer period, rewet the soil and improves root zone area through availing water during the peak hours. In prolonged moisture dry periods help plant to sustain turgidity within plant cell.

Improve $\mathrm{pH}$ and cation exchange capacity of soil. Pure zeolite materials usually have high CEC ranging from 220 to $570 \mathrm{cmolc}$ $\mathrm{kg}^{-1}$ [16]. Adding zeolites to a soil can increase the soil's overall CEC and $\mathrm{pH}$ in most cases (Ming and Allen, 2001), thus soil's nutrient holding capacity is enhanced. The large surfaced area of zeolitic material with slight alkalinity in nature acts as a buffering agent in soil. Zeolites, being of weakly alkaline reaction with the $\mathrm{pH}$ of around 8.0, can be combined with mineral fertilizers to maintain soil buffering and indirectly regulate soil $\mathrm{pH}$ thus reducing the need for lime application [4]. According to Colella (1999), the use of zeolitic volcanic tuff for acid soil conditioning led to effective $\mathrm{pH}$ buffering, neutralizes the hydrolytic and exchangeable acidity of soil.

\section{Remediation of contaminated soil}

The heavy metals pollution is increasing day by day due to heavy industrialization. Their excessive concentrations in soils often resulted from anthropogenic activities, such as the mining industry and processing of metal ores, waste incineration, road transport and the use of fertilizers and agrochemicals [17]. Heavy metals may persist in the soil for hundreds of years, which is associated with the risk of their inclusion in a trophic chain. For cleansing of these heavy pollutants, zeolite is a class of alkaline porous alumosilicates with negatively charged crystal lattice, neutralized by the presence of exchanged cations in the structural cavities $[18,19]$. They are being proven as a good amending material for the improvement of soil quality. They diminish the solubility and thus the biological availability of metals: salts, complexes, as well as oxides and metal-carbonate precipitates are formed with zeolites $[20,21]$. Zeolite could be used an effective additive to control the odour [22], as they could adsorb the volatile 
substances (Rodriguez et al. 1994) like acetic acid, butanoic acid, isovaleric acid, indole, skatole [23] and enhances effectiveness of the manure [24]. The utility of Ca-rich zeolites in Indian soils has been reported to ameliorate the bad effects of high $\mathrm{pH}$, sodium, magnesium and poor drainage.

\section{Enrichment of nutrient pool}

Zeolites are recognized as "intelligent fertilizer" because they can exchange cations allowing nutrients such as nitrogen, calcium, iron, magnesium, potassium, and water to be available in the plant and be eliminated slowly [25]. The nutrients are released gradually, not only in the first year of the vegetation period but also in the second or the following years. The most important nutrients necessary for proper growth and development of plants, are nitrogen, potassium, calcium and magnesium. Among, clinoptilolite could make an excellent amendment material for sand by stabilizing the nitrate leaching. They affect not only the size of the crop but also its quality. Zeolites can retain nutrients in the topsoil, which are slowly and gradually leached from the soil. This allows the use of smaller doses of fertilizer, which is associated with a reduction in the cost of crop production (DeLuca DK, 1997).

\section{Impact on microbial community}

The removal of heavy metals in polluted areas is always been difficult because they persist in soils for very longer periods. The ability to mineralize organic matters is a key function of soil microorganisms, its sensitivity to metal contamination has always been a subject of many studies (Giller at al. 1998). Susana Sfechis [26] found the suitability of using natural zeolite (clinoptilolite) in agriculture, having a positive role in plant nutrition and microbial community stability. The treatment with $30 \%$ zeolite $+70 \%$ urea in spring barley causes a positive effect on microbiological community. A wide range of carbon sources were metabolised by the microorganisms found in the soil type (amino sugar, amino acids except L-arginine, all the carboxylic acid and the neutral sugars). In another study, nitrifying bacteria could not use the manure-ammonia in the zeolite due to small pore size [27]. Chander and Joergensen [28] concluded the zeolite effects on soil microbial populations and their activities are unknown. The microbial populations could respond to zeolite amendment in different ways, but further studies should be performed to understand better the zeolite effects on soil microbial properties.

\section{Conclusion}

Generally, Zeolites are naturally occurring aluminosilicates minerals that are used as source of plant nutrients and soil amendments. In agriculture, applications of zeolites can be used directly to soils as materials for growth media, mixed with manures during decomposition process, and for mixing with urea as slow release agent $[29,30]$. Zeolites are helpful for improving nutrients use efficiencies because they are responsible for reducing the immobilization and leaching losses of nutrients.
Zeolites find many potential applications as it can be used as a soil amelioration for low cation exchange capacity of soils. It works as a mixing material for fertilizers, material for improvement of compost quality, material for water treatment of fishponds and in remediation of heavy metal contaminated soils. There is much more need of research efforts in India to exploit the potential of zeolites for the maintenance of soil health and productivity.

\section{References}

1. Pearson MS, Maenpaa K, Pierzynski GM, Lydy MJ (2000) Effects of soil amendments on the bioavailability of lead, zinc, and cadmium to earthworms. Journal of Environmental Quality 29(5): 1611-1617.

2. De Campos BAC, Peronti PAO, De Melo MMB, Polidoro JC, Souza BF (2010) Brazilian sedimentary zeolite use in agriculture. 19th World Congress of Soil Science: Soil Solution for a Changing World, Brisbane, Australia: Curran Associates, p. 37-40.

3. Ciocinta RC, Harja M, Bucur D, Rusu L, Barbuta M, et al. (2012) Improving soil quality by adding modified ash. Environmental and Engineering Management Journal 11(2): 297-305.

4. Polat E, Karaca M, Demir H, Naci OA (2004) Use of natural zeolite (clinoptilolite) in agriculture. Journal of Fruit Ornamental and Plant Research 12: 183-189.

5. Sukheswala RN, Avasia RK, Gangopadhyay M (1974) Zeolites and associated secondary minerals in the Deccan Traps of Western India. Min Mag 39: 658-671.

6. Walker (1969) Some observations and interpretations on the Deccan Traps.

7. Anant VP (1984) Natural occurrence of Clinoptilolite from Western Maharashtra: Its utilization in Refrigeration using solar energy. Proc Indian National Science Academy 50A (5): 479-482.

8. Bhattacharyya T, Pal DK, Deshpande SB (1993) Genesis and transformation of minerals in the formation of red (Alfisols) and black (Inceptisols and Vertisols) soils on Deccan basalt. J Soil Sci 44(1):159171.

9. Bhattacharyya T, Pal DK, Srivastava P (1999) Role of zeolites in persistence of high altitude ferruginous Alfisols of the Western Ghats, India. Geoderma 90(3-4): 263-276.

10. Bhattacharyya T, Chandran P, Ray SK, Pal DK, Mandal C, et al. (2015) Distribution of zeolitic soils in India. Current Science 109(7): 13051313.

11. Breck DW (1974) Zeolite molecular sieves. Wiley, New York.

12. Zygadło M, Seweryn A, Wozniak M (2010) Synthesis of zeolites based on fly ash from selected heat recovery installations. Waste Management and Environmental Protection Archives 12(1): 15-26.

13. Ming DW, Allen ER (2001) Use of natural zeolites in agronomy, horticulture and environmental soil remediation, in Natural Zeolites: Occurrence, Properties, Applications. In: Ming DW, Bish DB (Eds.), Mineralogical Society of America, Geochemical Society, Saint Louis, Mo, USA, Italian National Academy, Accademia Nationale dei Lincei (ANL), Barcelona, Italy pp. 619-654.

14. Githinji LJM, Dane JH, Walker RH (2011) Physical and hydraulic properties of inorganic amendments and modeling their effects on water movement in sand-based root zones. Irrigation Science 29(1): 65-77.

15. Voroney RP, Van Straaten P (1988) Use of natural zeolites in sand root zones for putting greens. Greenmaster Mag 8: 19. 
16. Boettinger JL, Ming DW (2002) Zeolites in Soil Mineralogy with Environmental Applications. In: Dixon JB, Schulze DG, SSSA Book Series 7 (Eds.), Soil Science Society of America, Madison, Wis, USA pp. 585610 .

17. Lado LR, Hengl T, Reuter HI (2008) Heavy metals in European soils: a geostatistical analysis of the FOREGS Geochemical database. Geoderma 148(2): 189-199.

18. Joshi UD, Joshi PN, Tamhankar SS, Joshi VP, Idage BB, et al. (2002) Influence of the size of extra framework monovalent cations in Xtypes zeolite on their thermal behaviour. Thermochim. Acta 373: 121-130.

19. Mondales KD, Carland RM, Aplan FF (1995) The comparative ion exchange capacities of natural sedimentary and synthetic zeolites. Miner Eng 8: 535-548.

20. Chlopecka A, Adriano DC (1996) Mimicked in-situ stabilization of metals in a cropped soil: bioavailability and chemical form of zinc. Environ Sci Technol 30(11): 3294-3303.

21. Querol X, Alastuey A, Moreno N, Alvarez AE, Garcia SA, et al. (2006) Immobilization of heavy metals in polluted soils by the addition of zeolite material synthesized from coal fly ash. Chemosphere 62(2): 171-180.

22. Sharadeqah SI, Al-Dwairi R (2010) Control of odorants emission from poultry manure using Jordanian natural zeolites. Jordan Journal of Civil Engineering 4(4): 378-388.

23. Cai L, Koziel JA, Liang Y, Nguyen AT, Xin H (2007) Evaluation of zeolite for control of odorants emission from simulated poultry manure storage. Journal of Environmental Quality 36(1): 184-193.

24. Leggo PJ (2000) An investigation of plant growth in an organo-zeolitic substrate and its ecological significance. Plant and Soil 219: 135-146.

25. Maria H, Sorin MC, Marcel D, Daniel B (2016) Synthesis of Zeolite from Fly Ash and their Use as Soil Amendment. Zeolites - Useful Minerals p. 43-66.

26. Susana S (2015) Researches influence of zeolite on productivity elements and microbiological activity on spring barley, soybeans and maize at ards turda. Ph.D. thesis, Library of UASVM Cluj-Napoca.

27. Mumpton FA (1999) La roca magica: Uses of natural zeolites in agriculture and industry. (In) Proceedings of National Academy of Science, USA 96(7): 3463-3470.

28. Chander K, Joergensen RG (2002) Decomposition of 14C labelled glucose in a $\mathrm{Pb}$-contaminated soil remediated with synthetic zeolite and other amendments. Soil Biol Biochem 34(5): 643-649.

29. Bhattacharyya T, Sharma JP, Srivastava R (1988) Weathered basalt - a soil conditioner. Indian Farming 38(4): 11-13.

30. Khachatryan V (2014) Heavy metal adsorption by Armenian natural zeolite from natural aqueous solution. Chemistry and Biology 2: 31-35.

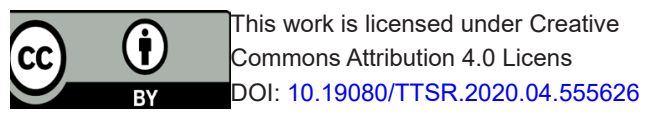

\section{Your next submission with Juniper Publishers} will reach you the below assets

- Quality Editorial service

- Swift Peer Review

- Reprints availability

- E-prints Service

- Manuscript Podcast for convenient understanding

- Global attainment for your research

- Manuscript accessibility in different formats

( Pdf, E-pub, Full Text, Audio)

- Unceasing customer service

Track the below URL for one-step submission https://juniperpublishers.com/online-submission.php 